\title{
MANAJEMEN LABA DAN RELEVANSI NILAI INFORMASI AKUNTANSI LABA DAN NILAI BUKU
}

\author{
Rahmat Haryo Wibowo \\ Unieversitas Brawijaya \\ J1. Veteran Malang 65145 Indonesia
}

\begin{abstract}
Management has an internal information and prospects of the company for more than investors. The availability of information held by the management than investors can lead to asymmetry of information and Opportunistic behavior can encourage management to select accounting policies in accordance with its interests through earnings management behavior. Investors will then choose the best information to make decisions. There are two general approaches used in assessing the performance of companies, ie earnings and book value approach.

Income approach gives information perperiode company operations, while the book value approach gives information on the net value of the company's resources in the long term. In addition, the approach has more elements of profit earnings management compared to book value.

There are indications of diminishing relevance value for each period due to various accounting-based trading activities and non-accounting and an indication of the increasing relevasi value. Some of the journals in this study tried to assert review whether there was an increase or decrease the relevance of the value of companies that conduct based on investor perceptions of earnings management.
\end{abstract}

Keywords: value relevance, earning management

Tujuan utama pelaporan keuangan adalah menyediakan informasi yang relevan bagi investor seperti yang dinyatakan dalam FASB's Statement of Financial Accounting Concept No.1: "Laporan keuangan seharusnya menyediakan informasi yang berguna untuk sekarang ini kepada investor, kreditor dan pengguna lainnya dalam membuat keputusan investasi, keputusan kredit dan keputusan-keputusan 
rasional lainnya, serta menilai jumlah, waktu dan ketidakpastian dari prospektif kas yang merupakan penerimaan-penerimaan deviden atau bunga dan hasil penjualan, penebusan hutang dan surat-surat berharga" FASB (1978, paragraf 34,37) dalam Lev dan Zarowin (1999).

Laba akuntansi dalam laporan keuangan merupakan salah satu parameter kinerja perusahaan yang mendapat perhatian utama dari investor. Untuk membuktikan hal ini, dapat menggunakan model pengujian EBO (Edward-BellOhloson) dalam Anggono dan Baridwan (2003), yang mengekspreksikan nilai perusahaan sebagai fungsi laba dan nilai buku. Hasil penelitian Collins et al., (1999) menunjukkan bahwa jika perusahaan rugi, pasar bersikap seolah-olah percaya pada nilai buku ekuitas baik sebagai proxy bagi pendapatan normal masa depan yang diharapkan dan sebagai proxy penlikuidasian.

Relevansi nilai merupakan salah satu area yang memberikan kontribusi besar dalam riset akuntansi berbasis pasar modal (Beaver 2002). Riset relevansi nilai berawal dari riset empiris akuntansi yang dilakukan Ball dan Brown tahun 1968 (Francis dan Schipper, 1999) melalui pengujian usefulness informasi laba akuntansi yang mempengaruhi rata-rata abnormal return pasar. Relevansi nilai dipahami sebagai kemampuan penjelas informasi angka akuntansi, terutama laba dan nilai buku terhadap harga sekuritas.

Menurut Francis dan Schipper (1999) terdapat empat kemungkinan intepretasi konstruk relevansi nilai: Intepretasi pertama, adalah informasi laporan keuangan mempengaruhi harga saham karena mengandung nilai intrinsik saham 
sehingga berpengaruh pada harga saham. Intepretasi kedua, informasi keuangan merupakan nilai yang relevan bila mengandung variabel yang dapat digunakan dalam model penilaian atau membantu dalam memprediksi variabel tersebut.

Intepretasi relevansi nilai yang ketiga dan keempat ditunjukkan oleh hubungan statistik antara informasi keuangan dengan harga atau return. Menurut intepretasi ketiga, relevansi nilai diukur dengan "berita" dari informasi yang bernilai relevan sehingga menyebabkan perubahan harga saham karena dengan adanya informasi tersebut menyebabkan investor merevisi ekspektasinya. Sedangkan menurut intepretasi keempat, relevansi nilai diukur dengan kemampuan informasi laporan keuangan untuk menangkap atau meringkas berbagai macam informasi yang mempengaruhi nilai saham.

Riset relevansi nilai secara spesifik melakukan pengujian argumentasi melalui prediksi asosiasi antara variabel dependen yang berbasis harga sekuritas dan variabel independen informasi akuntansi. Angka akuntansi dianggap memiliki nilai relevan bila secara signifikan berhubungan dengan variabel dependen. Riset relevansi nilai didasarkan pada dua kombinasi basis teoritis, yaitu valuation theory dan argumen kontekstual akuntansi tentang bagaimana variabel akuntansi berhubungan dengan nilai pasar ekuitas (Beaver, 2002). Riset relevansi nilai mengombinasikan pendekatan nilai buku dan laba akuntansi.

Riset relevansi nilai (misalnya, Jones, 1991; Ohlson, 1995; Dechow et al., 1995; Burgstahler dan Dichev, 1997; Francis dan Schipper, 1999; Barth et al., 1999; Marquardt dan Wiedman 2004) menyatakan relevansi nilai bergantung dari kualitas 
informasi yang tersedia. Ketersediaan informasi yang disajikan akan direspon investor untuk menilai kinerja perusahaan (Subramanyam, 1996; Beaver, 2002). Permasalahan yang berhubungan dengan relevansi nilai, yaitu apakah kualitas informasi yang disajikan sesuai kondisi perusahaan sesungguhnya.

Kualitas informasi berhubungan dengan perilaku penyusun laporan, yaitu pihak manajemen karena. Akses informasi internal dan prospek perusahaan di masa mendatang yang dimiliki lebih banyak oleh manajemen dibandingkan investor dapat menimbulkan asimetri informasi. Kondisi ini dapat mendorong pihak manajemen berperilaku opportunistic dan memilih kebijakan akuntansi sesuai dengan kepentingannya, di samping standar akuntansi memberikan fleksibilitas untuk memilih seperangkat kebijakan jika kinerja manajemen diukur berdasarkan laba (Healy, 1985). Perilaku disfunctional behaviour ini disebut sebagai perilaku manajemen laba (earning management).

Konsekuensi perilaku manajemen laba ini, yaitu laporan keuangan tidak lagi mencerminkan kondisi sesungguhnya dan menyebabkan investor tidak bisa menyandarkan diri sepenuhnya pada informasi yang disajikan untuk mengukur kinerja perusahaan (Marquardt dan Wiedman, 2004). Untuk menjamin ketersediaan informasi yang lebih baik, pihak investor berusaha mencari metode alternatif lain mengukur kinerja perusahaan.

Ohlson (1995), Brugstahler dan Dichev, (1997), Collins et al. (1997), Francis dan Schipper (1999), Barth et al. (1999), Beaver (2002), dan Marquardt dan Wiedman (2004) menyatakan terdapat dua cara pengukuran umum yang digunakan 
investor untuk menentukan nilai infomasi akuntansi, yaitu pendekatan rugi laba dan pendekatan neraca. Pendekatan rugi laba diukur berdasarkan nilai laba sedangkan pendekatan neraca diukur berdasarkan nilai buku. Meskipun demikian, terdapat pertentangan tentang relevansi nilai berdasarkan pendekatan laba dan nilai buku (Ohlson, 1995). Ohlson (1995) menyatakan pendekatan neraca lebih berguna menilai perusahaan dibandingkan pendekatan laba karena menggambarkan kondisi sumber daya perusahaan dengan lebih tepat. Barth dan Landsman (1995) menyatakan dalam pasar yang sempurna, fair value accounting based balance sheet lebih menyajikan seluruh informasi yang relevan, sedangkan income statement memberikan informasi yang terlalu berlebihan dan realisasi income yang tidak relevan. Brugstahler dan Dichev (1997), Francis dan Schipper (1999), dan DeFond (2002) menyatakan pendekatan nilai buku lebih dipercaya oleh pihak investor dibandingkan dengan pendekatan laba dengan alasan laba memberikan informasi operasi perusahaan per periode, sedangkan nilai buku memberikan informasi nilai bersih sumber daya perusahaan jangka panjang.

Relevansi nilai dapat didefinisikan sebagai nilai $\mathrm{R}^{2}$ regresi laba akuntansi dan nilai buku terhadap harga saham (Brown et al., 1999) atau nilai koefisien informasi akuntansi terhadap harga saham yang signifikan (Marquardt dan Wiedman, 2004). Beaver (1968) menyatakan relevansi nilai merupakan explanatory power dari informasi akuntansi, misalnya laba akuntansi dan nilai buku hubungannya dengan 
nilai perusahaan yang direpresentasikan dengan harga saham ${ }^{1}$. Angka akuntansi dianggap sebagai nilai yang relevan bila secara signifikan berhubungan dengan variabel dependen dan informasi laba rugi dan neraca merupakan bentuk relevansi nilai yang tercermin dalam harga saham ${ }^{2}$.

Hasil penelitian relevansi nilai menyatakan selama beberapa dekade terakhir terjadi penurunan relevansi nilai (Lev dan Zarrowin, 1999; Brown et al., 1999; Dontoh et al., 2004; Marquardt dan Weidman, 2004) dan peningkatan relevansi nilai (Collins et al., 1997; Francis dan Shipper, 1999; Coram, 2004) atas informasi akuntansi di pasar modal disebabkan berbagai faktor akuntansi dan non akuntansi.

Hasil penelitian Brown et a.l,. (1999), misalnya menunjukkan selama empat puluh tahun perkembangan pasar modal, kepercayaan terhadap informasi akuntansi mengalami penurunan karena kebutuhan informasi pemakai laporan keuangan yang tidak dapat dipenuhi oleh informasi akuntansi, menyebabkan investor berpaling pada informasi non akuntansi. Lev dan Zarrowin (1999) menemukan terjadinya penurunan relavansi nilai explanatory power dari informasi akuntansi, terutama earnings, aliran kas dan nilai buku karena terjadi kenaikan beban research and development. Dontoh et al., (2004) menguji prediksi teoritis yang muncul dari rasional gangguan ekspektasi model keseimbangan menjelaskan terjadi penurunan temporal asosiasi antara harga saham dan informasi akuntansi (laba dan nilai buku), yang kemungkinan terjadi

\footnotetext{
${ }^{1}$ Dua cara pengukuran relevansi nilai, yaitu berdasarkan nilai $\mathrm{R}^{2}$ dan nilai koefisien regresi variabel indepanden yang signifikan.

${ }^{2}$ Riset relevansi nilai menurut Beaver (2002) meningkat sejak tahun 1990-an terutama berkaitan dengan variabel dependen berbasis harga sekuritas maupun volume perdagangan hubungannya dengan set dari variabel-variabel akuntansi maupun non-akuntansi.
} 
akibat aktivitas perdagangan berbasis non-informasi, misalnya perubahan ekonomi capital-intensive tradisional menjadi teknologi tinggi. Teoh et al., (1998), Barth et al., (1999), dan Marquardt dan Weidman (2004) menemukan bukti meningkatnya nilai saham perusahaan yang melakukan manajemen laba selama penawaran saham dan kemudian menurun pada periode berikutnya. menemukan terjadinya penurunan relevansi nilai perusahaan yang melakukan manajemen laba.

Penulisan paper ini dimaksudkan untuk melakukan review beberapa jurnal penelitian yang berkaitan dengan relevansi nilai dari suatu laporan keuangan yang melakukan praktik earning management

\section{PEMBAHASAN}

\section{Relevansi Nilai yang Mengandung Manajemen Laba dan Pola Pergerakan Relevansi Nilai}

Manajemen laba merupakan cara yang digunakan manajemen untuk meningkatkan nilai laporan keuangan. Scott (2009:409) menyatakan terdapat banyak alasan yang mendasari manajemen melakukan manajemen laba. Dari sisi teori kontrak, manajemen laba dapat digunakan sebagai jalan untuk memperkecil biaya untuk melindungi perusahaan dari konsekuensi kontrak yang dilakukan dan dari sisi laporan keuangan manajer dapat mengubah nilai pasar perusahaan melalui tindakan manajemen laba.

Untuk semua alasan tersebut, manajer dapat memilih berbagai kebijakan akuntansi untuk mengambil kebijakan memaksimalkan nilai perusahaan. Healy 
(1985) menjelaskan dan mempredikasi perilaku manajer dalam melakukan pilihan terhadap kebijakan akuntansi. Hasil temuannya menyatakan manajer perusahaan cenderung untuk meningkatkan earnings perusahaan berdasarkan bonus plan. Dikatakan juga bahwa net income memotivasi manajer menggunakan kebijakan akuntansi agar income barada di antara bogey dan cap ${ }^{3}$. Beberapa motivasi manajer melakukan manajemen laba di samping rencana bonus, di antaranya yaitu: Motivasi kontraktual, motivasi politik, motivasi pajak, perubahan CEO, initial publik offering (IPO), dan untuk mengkominikasikan informasi kepada investor. Adapun pola dari manajemen laba menurut Scott (2009:410) yaitu: taking a bath, minimalisasi pendapatan, maksimalisasi pendapatan, income smoothing,

Beberapa literatur dan penelitian yang berhubungan dengan manajemen laba dan relevansi nilai (Solomons, 1995; Rangan, 1998; DeFond, 2002; Barth et al., 1999; Marquardt dan Wiedman, 2004) menyatakan relevansi nilai dari informasi akuntansi dipengaruhi oleh perilaku manajemen laba. Relevansi nilai secara umum dihasilkan dari dua model pengukuran yaitu berdasarkan laporan rugi laba dan neraca.

\section{Manajemen Laba dan Relevansi Nilai}

Manajemen laba merupakan implementasi kebijakan yang menyebabkan elemen yang digunakan untuk membuat keputusan menjadi kurang bermakna atau

\footnotetext{
${ }^{3}$ Bogey dan cap diartikan sebagai batas atas dan batas bawah rencana perusahaan dalam penentuan secema bonus. Untuk penjelasan lebih lanjut dapat dilihat dalam Scott (2003).
} 
implementasi yang tidak konsisten dengan standar (Schipper, 1999 dalam Fields et al., 2001). Healy dan Wahlen (1999) menyatakan manajemen laba terjadi ketika kebijakan manajemen terhadap laporan keuangan, mengubah struktur laporan keuangan yang menyebabkan stakeholder bias menilai kinerja ekonomi perusahaan atau mempengaruhi outcome contractual yang tergantung pada pelaporan angka akuntansi. Manajemen laba dapat digunakan untuk menyembunyikan informasi privat atau mengubah bentuk laporan laba sesuai keinginan manajemen. Seperti yang dinyatakan oleh Marquardt dan Wiedman (2004), konsekuensi perilaku manajemen laba ini menjadikan laporan keuangan tidak lagi mencerminkan kondisi yang sesungguhnya dan menyebabkan pihak investor tidak bisa menyandarkan diri pada informasi yang disajikan untuk mengukur kinerja perusahaan. Untuk menjamin ketersediaan informasi yang lebih baik, pihak investor berusaha mencari metoda alternatif lain mengukur kinerja perusahaan yaitu berdasarkan laba dan nilai buku.

Anggono dan Baridwan (2003) menyatakan bahwa terdapat perbedaan antara relevansi nilai laba, nilai buku dan dividen. Namun terdapat ketidakkonsistenan dengan hasil penelitian brief dan zarowin (1999) yang menemukan nilai buku lebih dominan dibandingkan dua variabel lainnya. DeFond (2002) menyatakan penelitian yang berhubungan dengan manajemen laba cenderung difokuskan pada income ststement sebagai implikasi dari tindakan manajemen laba pada proses akuntansi. Partisipan pasar (investor) lebih menyukai penggunaan informasi yang berasal dari neraca karena membantu lebih memahami memprediksi earnings perusahaan ke depan. 
Brugstahler dan Dichev, (1997) melakukan uji model penilaian earnings dan nilai buku terhadap nilai pasar perusahaan menggunakan data penelitian dari tahun 1976-1994. Penelitiannya menggunakan variabel market value (MV), book value (BV), dan earnings (E), serta menggunakan varaibel perubahan $\mathrm{MV}, \mathrm{BV}$, dan $\mathrm{E}$ secara cross section dan pooled. Hasil penelitiannya menggunakan cross section dan pooled menemukan nilai variabel earnings yang siginfikan untuk seluruh regresi sampel, sesuai dengan teori relevansi nilai atas earnings dan menemukan penurunan nilai $\mathrm{R}^{2}$ dari tahun 1976 sampai dengan tahun 1994. Brughstaler dan Dichev (997) menggunakan variabel perubahan $\mathrm{MV}, \mathrm{BV}$, dan $\mathrm{E}$ serta variabel kontrol middle range (DM) dan high range (DH) yang diperoleh dari cutoff E/BV juga menunjukkan hasil yang konsisten, yaitu nilai buku lebih berguna menentukan nilai saham perusahaan dibandingkan dengan earnings jika nilai earnings/book value rendah dan earnings berguna untuk menentukan nilai perusahaan jika terjadi peningkatan earnings setiap tahunnya.

Francis dan Schipper (1999) menguji relevansi nilai informasi akuntansi menggunakan data tahun 1952-1994. Penelitiannya menggunakan pengukuran relevansi nilai dari variabel SIGN_EARN dan $\triangle$ EARN sebagai proksi dari laporan rugi laba, dan $\triangle \mathrm{CASH}$, RATIO 1, RATIO 2, ASSET, dan LIAB sebagai proksi dari neraca. Hasil penelitiannya menemukan relevansi nilai return berdasarkan earnings mengalami penurunan, sedangkan relevansi nilai return nilai asset dan liability, dan kombinasi nilai buku aset dan liabilities dan earnings tidak mengalami penurunan. 
Kesimpulan penelitiannya yaitu pendekatan nilai buku memiliki relevansi nilai lebih tinggi dibandingkan pendekatan earnings.

Marquardt dan Wiedman (2004) meneliti apakah oportunisasi perilaku manajemen laba berpengaruh terhadap relavansi nilai net income dan nilai buku. Penelitiannya menggunakan model discretionary accrual Jones (1991) untuk menyeleksi sampel perusahaan yang melakukan manajemen laba dan tidak melakukan manajemen laba pada perusahaaan yang melakukan equity offering dengan sampel sebanyak 192 pada tahun 1984-1991. Variabel net income (NI), book value (BV) serta beberapa variabel kontrol SIZE, GROWTH, dan LEVERAGE digunakan dalam penelitiannya. Hasilnya menemukan net income memiliki relevansi lebih rendah dibandingkan nilai buku.

\section{Pola Pergerakan Relevansi Nilai}

Relevansi nilai didefinisikan sebagai hubungan antara informasi akuntansi dan nilai pasar saham (Francis dan Shipper, 1999; Barth, Beaver, dan Landsman, 2001). Pengukur relevansi nilai adalah kekuatan penjelas secara menyeluruh dari informasi akuntansi terhadap harga saham (Marqardt dan Wiedman, 2004) yang diukur menggunakan nilai $\mathrm{R}^{2}$. Brown, et al., (1999) menyatakan penelitian biasanya melakukan regresi stock prices on earnings per share untuk mengestimasi relevansi nilai informasi akuntansi yang akan menghasilkan $\mathrm{R}^{2}$ yang memiliki nilai mendekati nol. Nilai $\mathrm{R}^{2}$ ini selanjutnya digunakan untuk mengukur relevansi nilai. Jika terjadi peningkatan nilai $\mathrm{R}^{2}$ secara terus menerus berarti terjadi peningkatan relevansi nilai 
dan sebaliknya. Metoda pengukuran lain relevansi nilai adalah nilai koefisien dari variabel akuntansi yang dianalisis (Marqardt dan Wiedman, 2004). Peningkatan riset relevansi nilai yang signifikan, disebut Beaver (2002) telah mendominasi era riset tahun 1990-an terutama berkaitan dengan variabel dependen berbasis harga sekuritas maupun volume perdagangan hubungannya dengan set dari variabel-variabel akuntansi maupun non-akuntansi ${ }^{4}$.

Sloan (1996) menyatakan pada awalnya nilai pasar saham perusahaan yang melakukan kebijakan akuntansi akrual akan meningkat dan kemudian menurun pada tahun berikutnya karena pergeseran laba tahun ke depan ke periode sekarang. Kenaikan nilai saham perusahaan yang melakukan manajemen laba pada saat dilakukannya penawaran saham hanya bersifat sementara dan akan menurun pada periode berikutnya seiring dengan menurunnya laba.

Collins et al., (1997) menguji perubahan sistematis relevansi nilai berdasarkan earnings (E) dan book value (BV) selama empat puluh periode menggunakan sampel tahun penelitian 1953-1993 perusahaan NYSE, AMEX, dan NASDAQ. Penelitiannya juga menggunakan variabel TIME untuk melihat hubungan antara periode waktu untuk mengetahui peningkatan (penurunan) relevansi nilai. Hasil temuannya menyatakan kombinasi relevansi nilai berdasarkan pendekatan earnings dan nilai buku tidak mengalami penurunan selama kurun waktu empat puluh tahun dan

${ }^{4}$ Holthausen dan Watts (2001) mengidentifikasi riset relevansi nilai sebanyak 54 riset di era 1990-an dan hanya 3 riset yang dilakukan sebelum tahun 1990. Riset relevansi nilai meskipun telah lama merupakan satu bentuk arah riset, akhir-akhir ini mulai banyak dilakukan setelah tahun 1990-an terutama berkaitan dengan variabel dependen berbasis harga sekuritas maupun volume perdagangan hubungannya dengan set dari variabel-variabel akuntansi maupun non-akuntansi. 
relevansi nilai beradasarkan earnings mengalami penurunan dan digantikan oleh nilai buku, namun keduanya secara signifikan mengalami peningkatan per periode.

Brugstahler dan Dichev (1997) melakukan uji model penilaian earnings dan nilai buku terhadap nilai pasar perusahaan menggunakan data penelitian dari tahun 1976-1994. Penelitiannya menggunakan variabel market value (MV), book value (BV), dan earnings (E), serta menggunakan varaibel perubahan $\mathrm{MV}, \mathrm{BV}$, dan $\mathrm{E}$ secara cross section dan pooled. Hasil penelitiannya menggunakan cross section dan pooled menemukan nilai variabel earnings yang siginfikan untuk seluruh regresi sampel, sesuai dengan teori relevansi nilai atas earnings dan menemukan penurunan nilai $\mathrm{R}^{2}$ dari tahun 1976 sampai dengan tahun 1994.

Barth et al., (1999) meneliti hubungan increasing earnings terhadap nilai pasar perusahaan. Penelitiannya menggunakan data seluruh perusahaan yang terdaftar di Compustat tahun 1982-1992 dengan beberapa model pengujian menggunakan variabel PRICE (harga saham), net income (NI), book value (BV), dan beberapa variabel kontrol lain seperti GROWTH (pertumbuhan) dan debt to equity (DE). Penelitiannya menemukan price-earning multiple ${ }^{5}$ perusahaan yang melakukan increasing earning akan lebih tinggi dibandingkan perusahaan lain dan pola increasing earnings berhubungan positif dengan pertumbuhan perusahaan dan berhubungan negatif dengan risiko. Terdapat hubungan positif antara price multiple earnings dengan earnings perusahaan. Selanjutnya, terjadi penurunan price-earning multiple pada periode setelah dilakukannya increasing earning oleh perusahaan.

${ }^{5}$ koefisien regresi harga saham terhadap perubahan laba 
Hasil temuannya juga menyatakan perusahaan dengan perutumbuhan earning yang konstan dinilai lebih tinggi dibandingkan perusahaan lain.

Rangan (1998) meneliti perusahaan yang melakukan penawaran saham pada menggunakan sampel sebanyak 230 perusahaan tahun 1987-1990. Hasil penelitiannya menemukan pada saat saham ditawarkan, terjadi peningkatan abnormal stock return berasarkan laba dan akan menurun pasca pengumuman. Penurunan ini disebabkan karena perusahaan melakukan transitory increases in earnings selama periode penawaran saham. Pada periode berikutnya, harga saham perusahaan akan menurun karena perusahaan melaporkan laba yang rendah. Ditemukan juga discretionary accrual selama periode penawaran berhubungan negatif dengan perubahan laba tahun berikutnya dan menyimpulkan pasar saham tidak mengetahui discretionary accrual yang dilakukan perusahaan.

Francis dan Schipper (1999) menguji relevansi nilai informasi akuntansi selama periode 1952-1994 dan menemukan relevansi nilai return berdasarkan earnings mengalami penurunan. Hasil pengujian relevansi nilai return berdasarkan nilai buku aset dan liabilities baik secara parsial yang dikombinasikan dengan earnings tidak mengalami penurunan. Francis dan Schipper (1999) juga menguji apakah penurunan relevansi nilai disebabkan oleh perubahan teknologi yang diadopsi perusahaan. Pengujian dilakukan menggunakan perusahaan teknologi tinggi dan perusahaan non teknologi tinggi. Hasil pengujian mengindikasikan hal yang sama dengan pengujian menggunakan seluruh sampel yaitu perusahaan dengan teknologi 
tinggi tidak mengalami penurunan relavansi nilai dibandingkan dengan perusahaan non teknologi tinggi.

Teoh et al., (1998) menguji perilaku manajemen laba selama periode penawaran ekuitas perusahaan menggunakan sampel sebanyak 6836 dari tahun 19761989. Penelitiannya dibagi menjadi beberapa periode penelitian mulai dari t-3 sampai dengan $\mathrm{t}+3$ untuk melihat pergerakan relevansi nilai. Hasil penelitiannya menemukan terjadinya manajemen laba melalui discretionary accrual yang meningkat sebelum periode penawaran, memuncak pada periode penawaran, dan menurun setelah periode penawaran. Penurunan net income yang terjadi setelah periode penawaran disebabkan karena perusahaan telah melakukan discretionary accrual yang agresif sebelum periode penawaran. Hasil penelitiannya juga menemukan hubungan negatif antara discretionary accrual sebelum dan sesudah penawaran ekuitas.

Lev dan Zarrowin (1999) melakukan pengujian kembali terhadap relevansi nilai informasi akuntansi dan menemukan terjadinya penurunan explanatory power dari informasi akuntansi, terutama earnings, aliran kas dan nilai buku selama dua puluh tahun. Penelitiannya menggunakan sampel sebanyak 1.300 perusahaan di file Compustat tahun 1978-1996 dan menggunakan variabel earnings, cash flow, dan book value untuk mengukur relevansi nilai $(\mathrm{ERC})^{6}$. Alasan dari penurunan nilai ini dikarenakan selama dua puluh tahun perkembangan pasar modal, terjadi perubahan dalam bisnis dan terjadi kenaikan beban research dan development yang direspon positif oleh investor.

\footnotetext{
${ }^{6}$ Lev dan Zarrowin (1999) mengukur relevansi nilai menggunakan earning respon coefficient (ERC).
} 
Dontoh et al., (2004) yang menguji prediksi teoritis yang muncul dari rasional gangguan ekspektasi model keseimbangan menjelaskan telah terjadi penurunan temporal dalam asosiasi antara harga saham dan informasi akuntansi (laba dan nilai buku), yang kemungkinan terjadi akibat aktivitas perdagangan berbasis non-informasi (non-information based atau NIB). Penelitiannya membandingkan antara relevansi nilai berdasarkan informasi akuntansi dan relevansi nilai berdasarkan NIB. Relevansi nilai informasi akuntansi diukur menggunakan variabel net income (NI) dan book value (BV) dan relevansi nilai NIB diukur menggunakan residual yang diperoleh dari persamaan relevansi nilai informasi akuntansi. Sampel penelitian menggunakan data perusahaan di Compustat tahun 1983-2000. Hasilnya menemukan relevansi nilai berdasarkan net income dan book value mengalami penurunan, terlihat dari nilai $\mathrm{R}^{2}$ regresi harga saham dalam informasi akuntansi yang menurun. Nilai $\mathrm{R}^{2}$ yang diperoleh dari persamaan regresi net income dan book value juga ditemukan berhubungan negatif dengan NIB, dan disimpulkan menurunnya relevansi nilai informasi akuntansi (net income dan book value) disebabkan oleh NIB.

Marquardt dan Wiedman (2004) menguji relevansi nilai berdasarkan pendekatan earnings dan nilai buku perusahaan yang melakukan manajemen laba. Menggunakan sampel sebanyak 192 yang dibagi menjadi sampel perusahaan yang sahamnya dimiliki oleh kelompok manajemen sebanyak 199 observasi dan sampel perusahaan yang sahamnya tidak dimiliki oleh kelompok manajemen sebanyak 73 observasi dengan total sampel sebanyak 192 observasi pada tahun 1984-1991. 
Periode penelitiannya dibagi menjadi beberapa perioda penelitian, yaitu $t_{-1}, t_{0}, t_{+1}, t_{+2}$, dan $t_{+3}$ untuk melihat pola pergerakan relevansi nilai $\left(R^{2}\right)$ selama beberapa waktu setelah dilakukannya sasoned equity offering. Ditemukan bukti terjadi penurunan relevansi nilai pendekatan earnings perusahaan dan terjadi peningkatan relevansi nilai informasi atas nilai buku. Hasil pengujian menggunakan sampel perusahaan yang melakukan discretionary accrual dan non discertionary accrual juga memberikan kesimpulan sama, yaitu terjadi penurunan relevansi nilai setiap tahunnya. Hasil penelitiannya menyimpulkan pendekatan nilai buku berperan lebih penting menentukan relevansi nilai ketika perusahaan melakukan manajamen laba.

\section{KESIMPULAN}

Manajemen memiliki informasi internal dan prospek perusahaan yang lebih banyak dibandingkan investor. Ketersediaan informasi yang dimiliki pihak manajemen dibandingkan investor dapat menimbulkan asimetri informasi dan dapat mendorong perilaku opportunistic manajemen untuk memilih kebijakan akuntansi sesuai dengan kepentingannya melalui perilaku manajemen laba. Investor selanjutnya akan memilih informasi yang terbaik untuk mengambil keputusan. Terdapat dua pendekatan umum digunakan menilai kinerja perusahaan, yaitu pendekatan laba dan nilai buku. Pendekatan laba memberi informasi operasi perusahaan perperiode, sedangkan pendekatan nilai buku memberi informasi nilai bersih sumber daya perusahaan dalam jangka panjang. Selain itu, pendekatan laba memiliki lebih banyak unsur manajemen laba dibandingkan nilai buku. 
Dari beberapa jurnal yang di bahas diatas dapat kita lihat bahwa sebenarnya masih ada pertentangan bagaimana sebenarnya relevansi nilai suatu laporan keuangan, baik dengan pendekatan laba maupun pendekatan neraca. Namun hasil yang paling dominan adalah investor cenderung lebih menggunakan penedekatan neraca dan informasi lainnya diluar laporan keuangan untuk menentukan keputusan melakukan investasi, sedangkan dengan pendekatan laba beberapa bahasan diatas dikemukakan bahwa semakin lama relevansi nilai dari pendekatan earning semakin lama akan semakin menurun, hal ini dikarenakan sangat besar kemungkinannya informasi itu mengandung managemen laba. Tetapi dari manapun dan alat apapun yang nantinya akan digunakan investor sebagai sarana untuk pengambilan keputusan informasi, adanya managemen laba yang mencoba mempercantik laporan keuangan sebenarnya tidak akan bisa membohongi calon investor karena investor mempunyai beberapa alternative informasi lain yang akan mempengaruhinya dalam berivestasi.

\section{DAFTAR PUSTAKA}

Anggono, Alexander dan Zaki Baridwan. (2003). Pengaruh Kebijakan Pembagian Deviden, Kualitas Akrual Dan Ukuran Perusahaan Pada Relevansi Nilai Deviden, Nilai Biku Dan Laba, Simposium Nasional Akuntansi VI, 393-403.

Ball, R. and P. Brown. (1968). An Empirical Evaluation of Accounting Income Numbers. Journal of Accounting Research. Vol. 6 (Autumn). pp. 159-178. 
Barth, M.E., and WR Landsman. (1995). Fundamental Issues Related to Using Fair Value Accounting for Financial Reporting. Accounting Horizon. Vol. 9 No. 4. pp. 97-107.

Barth, ME., John A. Elliot, and Mark W. Finn. (1999). Market Rewards Associated With pattern on Increasing Earning. Journal of Accounting Research. Vol. 2 (Autumn). pp. 387-413.

Barth, ME., W.H. Beaver and W.R. Landsman. (2001). The Relevance of Value Relevance Research for Financial Accounting Standard Setting: Another View. Journal of Accounting and Economics. Vol. 39 (September). pp. 77104.

Beaver, William H. (1968). The Information Content of Earnings. Journal of Accounting Research. Vol. 6 (supplement) pp. 67-92.

Beaver, William H. (2002). Perspectives on Recent Capital Market Research. The Accounting Review. Vol. 7 (2) April. pp. 453-474.

Brown, Stephen., Kin Lo and Thomas Lys. (1999). Use of $\mathrm{R}^{2}$ in Accounting Research: Measuring Changes in Value Relevance Over the Last Four Decades. Journal of Accounting and Economics. Vol. 28. pp. 83-115.

Burgstahler, D. and I. Dichev. (1997) Earning, Adaption, and Equity Value, The Accounting Review, Vol. 72 pp187-215.

Collins, Daniel W., Edward L. Maydew, and Ira S. Weiss. (1997). Changes in the Value Relevance of Earnings and Book Values Over the Past Forty Years. Journal of Accounting and Economics. Vol. 24. pp. 39-67.

Coram, Paul. (2004). An Experimental Evaluation of the Effect of Voluntary Disclosure of Non-Financial Performance Indicators and Assurance on this Information on Stock Price Estimation and Earnings Forecasts. Paper from PhD. Dissertation. Australian National University.

Dechow, P, R. Sloan and Sweeney. (1995). Detecting Earning Management. The Accounting Review. Vol. 70 pp.193-226.

DeFond, Mark L. (2002). Discussion of the Balance Sheet as an Earnings Management Constraint. The Accounting Review. Vol. 77 pp.29-33.

Dontoh, Alex., Suresh Radhakrishnan and Joshua Ronen. (2004). The Declining Value Relevance of Accounting Information and Non-Information-Based 
Trading: An Empirical Analysis. Contemporary Accounting Research. Vol. 21 pp. 793-812.

Francis, Jennifer and Catherine Schipper. (1999). Have Financial Statements Lost Their Relevance. Journal of Accounting Research. Vol. 37 (2). pp. 319-352.

Fields D. Thomas, Thomas Z. Lys, and Linda Vincent. (2001). Empirical Research on Accounting Choice. Journal of Accounting and Economics. Vol. 31. pp. 255307.

Healy, P. (1985). The The Impact of Bonus Scheme on Selection of Accounting Principles. Journal of Accounting and Economic.

Healy, P. And J.M. Wahlen. (1999). A Review of Earning Managements Literature and Its Implication for Standart Setting. Accounting Horizon Vol. 13 pp.365384.

Holthasen and Watss, 2001. The Relevance of Value Relevance Literatur for Financial Accounting Standar Setting. Journal of Accounting and Economic.

Jones, Jeniffer J. (1991). Earnings Management During Import Relief Investigation. Journal of Accounting Research, Vol. 29 No 2 Autumn.

Lev, Baruch and Paul Zarowin. (1999). The Boundaries of Financial Reporting and How To Extend Them. Journal of Accounting Research. Vol. 37 (2). pp. 353385.

Marquardt, Carol A. dan Christine I. Weidman. (2004). The Effect Of Earnings Management On Value Relevance Of Accounting Information. Journal of Business Finance and Accounting.

Ohlson, James A. (1995). Earnings, Book Values, and Dividen in Equity Valuation. Contemporary Accounting Research, Vol. 11 No 2 Spring.

Sloan, R.. (1996). Do Stock Price fully Reflect Information in Accruals and Cash Flow About Future Earnings? The Accounting Review.

Scott, W.R. (2009). Financial Accounting Theory. Canada: Pearson Prentice-Hall.

Subramanyam, K. R.. (1996). The Pricing of Discretionary Accrual. Journal of Accounting and Economic. Vol. 22 pp. 249-281. 
Teoh Siew Hong, Ivo Welch, and T.J. Wong. (1998). Earning Management and the Underperformance of Seasoned Equity Offering. Journal of Financial Economic. Vol. 50 pp.63-99. 